\title{
The Environmental Impact of Sturgeon Pen Culture on Diversity and Spatial Distribution Patterns of the Benthic Macro Fauna Communities in Gorgan Bay
}

\author{
Farhangi Mohammad ${ }^{1}$, Hosseini Seyed Abbas ${ }^{2}$, Jafaryan Hojatollah ${ }^{1}$, Ghorbani Rasoul ${ }^{2}$, Harsij Mohammad ${ }^{1} \&$ \\ Sudagar Mohammad ${ }^{2}$ \\ ${ }^{1}$ Department of Agricultural and Natural Resources, Gonbad Kavous University, Gonbad, Iran \\ ${ }^{2}$ Department of Fisheries and Environment, Gorgan University of Agricultural Science and Natural Resources, \\ Gorgan, Iran \\ Correspondence: Farhangi Mohammad, Department of Agricultural and Natural Resources, Gonbad Kavous \\ University, P. O. Box: 163, Gonbad, Iran. E-mail: s.farhangi@yahoo.com
}

Received: September 6, 2019

Accepted: September 26, 2019

Online Published: September 29, 2019

doi:10.5539/ep.v8n2p31

URL: https://doi.org/10.5539/ep.v8n2p31

\begin{abstract}
Community structure and biodiversity of benthic macro fauna in around pen culture of Sturgeon fish in Gorgan Bay were studied for period of one year from August 2015 to July 2016. Seasonal samplings were carried out at 5 stations in 3 transects. In addition, depth (D), water temperature $\left(\mathrm{T}^{\mathrm{oc}}\right)$, dissolved oxygen (DO); $\mathrm{pH}$, total dissolved solid (TDS), biological oxygen demand $\left(\mathrm{BOD}_{5}\right)$, chemical oxygen demand (COD), phosphorus $\left(\mathrm{PO}_{4}^{-3}\right)$, nitrite $\left(\mathrm{NO}_{2}{ }^{-}\right)$and total ammonia $\left(\mathrm{NH}_{3}{ }^{+}\right)$were measured in each station. Results of season variations of Physico chemical factors of water showed that, there were no significant differences between $\mathrm{PO}_{4}^{-3}(p>0.05)$. However, there were significant differences between $\mathrm{BOD}_{5}, \mathrm{COD}, \mathrm{NO}_{2}^{-}, \mathrm{NH}_{3}{ }^{+}$and TDS $(p<0.05)$. Totally, 11 genus's and 10 families belong to 3 phyla as Mollusks, Arthropods and Annelids were identified. The results showed, there were the maximum abundance percent belong to Hydrobiidae and Cochliopidae with $33.83 \%$ and $26.25 \%$ and the minimum abundance percent belong to Gammaridae with $0.05 \%$ respectively. However, the maximum abundance belongs to Pyrgohydrobia sp., from Hydrobiidae with $3410 \mathrm{n} / \mathrm{m}^{2}$. The results showed, there were the maximum and minimum abundance percent in autumn and spring with 1.07 and $0.88 \%$ respectively. The results of distance-based redundancy analysis (db.-RDA) revealed that environmental factors such as depth, DO and TDS are all important in determining the distribution of macro benthic species in Gorgan Gulf. However, there were significant differences between abundance, species number (S), diversity (as Shannon-Wiener's, H'), species richness (as Margalef's, D), and evenness (as Pielou's, J) $(p<0.05)$. There were the most diversity species in 2 and 5 stations.
\end{abstract}

Keywords: biodiversity, Macro fauna, environmental factors, Gorgan bay

\section{Introduction}

Gorgan Bay is a unique ecosystem in the south-eastern part of the Caspian Sea. It is separated by Miankaleh peninsula from the sea. Sediment texture is different from west to east (Lahijani et al., 2002; Lahijani et al., 2010). Salinity regime is different throughout the bay and it is influenced by internal current (Sharbaty, 2012) and some small rivers from east and west which created some freshwater marshes especially at the western part (Taheri et al., 2012). Therefore, different types of habitats are found in the bay (e.g., salt marsh, mud flat, sand flat, fresh and brackish water area) and each type is inhabited by different species (com- munity structure). These variable conditions made it the most important natural ecosystem in the south part of the Caspian Sea that serves as a nursery area for a lot of juvenile fishes and very good place for breeding and wintering of the water birds

The macro fauna play important roles in marine ecosystems, involving nutrient cycling, dispersion, sediment burial, and secondary production. Distribution patterns in general are related to environmental factors such as tidal currents, depth, food supply, salinity, sediment texture, organic matter content and current velocity (Gogina et al., 2010; Nicastro and Bishop, 2013). Hence, any changes in environmental conditions can be reflected in macro fauna community characteristics. Response of macro benthic species to these conditions is different and related to their adaptation strategies (Baldanzi et al., 2013; Conde et al., 2013). In fact, most of the species 
cannot migrate out of the habitat, and adapt to the changes of environmental conditions (Dauer, 1993). Therefore, there is a growing need to understand species-environment relationships due to increasing pressure on the marine environment (Snickars et al., 2013). Although a few studies have described macro benthic fauna in the Gorgan Bay (Aghili et al., 2014; Dorostkar, 2007; Saghali et al., 2012; Tajari et al, 2013) data about the species-environment relationships are almost absent. The purpose of this paper was to study of effects of Sturgeon pen culture on macro benthic community structure and study biodiversity of macro benthic in Gorgan Bay. These results can help us to evaluate environmental and man-made changes on fauna, and monitoring the effect of invasive species and manage this area in the future.

\section{Materials and Methods}

\subsection{Study Area}

Gorgan Bay is located in an east-west direction in the Golestan Province, southeast coast of the Caspian Sea, Iran. Its area is around $400 \mathrm{~km} 2$ with the maximum length of $70 \mathrm{~km}$. Most part of the bay has low depth (less than $2 \mathrm{~m}$ ), the maximum depth is $5 \mathrm{~m}$ and it decreases from east to west. The study was done around of Sturgeons pen culture sites in Ashoradeh peninsula, Bandar-Turkman, Golestan Province. The studied were conducted out one year from August 2015 to July 2016. Seasonal samplings were carried out at 5 stations in 3 transects (Fig. 1), which were in distance 0, 5, 25, 50 and $100 \mathrm{~m}$ from pen sites. Sampling was conducted on the Gorgan Bay within $36^{\circ} 53^{\prime} 51.09^{\prime \prime}$ to $36^{\circ} 52^{\prime} 53.59^{\prime \prime} \mathrm{N}$ and $53^{\circ} 58^{\prime} 39.05^{\prime \prime}$ to $53^{\circ} 58^{\prime} 43.85^{\prime \prime}$ E.

\subsection{Environmental Factors}

At each station, water temperature $\left(\mathrm{T}^{\mathrm{OC}}\right)$, dissolved oxygen (DO), total dissolved solid (TDS) and $\mathrm{pH}$ were measured using a multi parameters (HACH- HQ 40d), depth (D) were measured using HANDEX- PS7 , biological oxygen demand $\left(\mathrm{BOD}_{5}\right)$ were measured using $\mathrm{BOD}$ meter (BOD track $-\mathrm{HACH}$ ), chemical oxygen demand (COD) and phosphorus $\left(\mathrm{PO}_{4}^{-3}\right)$, nitrite $\left(\mathrm{NO}_{2}{ }^{-}\right)$and ammonia $\left(\mathrm{NH}_{3}{ }^{+}\right)$were measured using HACH-DRB 200 and $\mathrm{HACH}-\mathrm{DR} 2800$ respectively. Water samples were collected in triplicates using a water sampler (NESKIN model DENMARK A/S), from bottom waters. Water samples collected were kept in 0.5-L dark bottles and cooled in the cooler box with ice blocks to prevent oxidation of the samples and was brought back to the laboratory for analysis within 24h. (Nyanti et al, 2012; Sanz-Lázaro and Marín, 2011).

\subsection{Data Collection}

At each station, three replicate samples of benthos were collected using a van Veen grab $(20 * 25 \mathrm{~cm})$. In the field, the contents of each grab were stored in the separate plastic containers. In the laboratory, sediment of each container is gently sieved by $0.5 \mathrm{~mm}$ mesh and the retained material is fixed in $4 \%$ buffered formalin and stained with Rose Bengal (Abowei et al., 2012; Taheri et al., 2011). Then, in the laboratory macro fauna were separated, identified and counted under a stereomicroscope. Most specimens were identified to Genus.

Density, abundance percent and biomass were calculated for groups. Then, diversity (as Shannon-Wiener's, H'), species richness (as Margalef's, D), and evenness (as Pielou's, J) dominant (as Simpson's, 1-D) were Calculated per square meter.

\subsection{Analysis Data}

Collected data were tested for normality (using Shapiro-Wilk). Significance of all tests was accepted at $\mathrm{P}<0.05$. Whenever data were normal, one-way analysis of variance (ANOVA) was used to test the differences among Physico-chemical factors and the biological parameters (density, mean species number, diversity, richness and evenness). LSD test $(\mathrm{P}<0.05)$ was used to assess the significant differences among the stations (in SPSS Version 16).

Distance-based redundancy analysis (db-RDA) was performed to identify the relationships among environmental variables and macro fauna assemblage structures using CANOCO software (Braak and Smilauer, 1998) with the software options set for forward selection to test the significance of environmental variables. All figures dependent of analysis were made by Excel and Primer programs. 


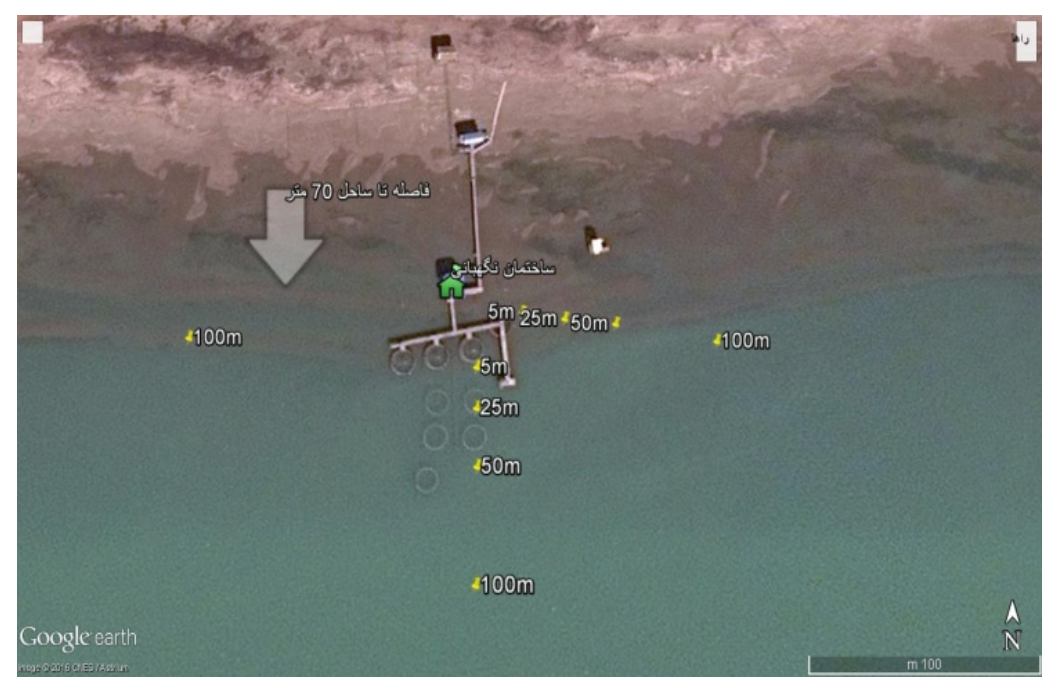

Figure 1. Location of the sampling stations on the Gorgan Bay (Google Earth)

\section{Results}

\subsection{Environmental Condition}

Environmental conditions are shown in Table 1. There were no significant differences between $\mathrm{T}^{\mathrm{oc}}$, Turbidity, TDS, and $\mathrm{PO}_{4}^{-3}(p>0.05)$. However, there were significant differences between $\mathrm{D}, \mathrm{DO}, \mathrm{pH}, \mathrm{BOD}_{5}, \mathrm{COD}, \mathrm{NO}_{2}^{-}$, $\mathrm{NH}_{3}{ }^{+}$and TDS $(p<0.05)$. For example, $\mathrm{BOD}_{5}$ values varied between $1.97 \pm 0.13$ at station 3 in winter and $5.24 \pm$ 73.5 at station 2 in spring.

\subsection{Community Structure}

Identified macro fauna in samples were belonging to ten families (Table 2). The maximum abundance percent belong to Hydrobiidae and Cochliopidae with $33.83 \%$ and $26.25 \%$ and the minimum abundance percent belong to Gammaridae with $0.05 \%$ respectively. Balanus sp., $11.90 \%$, Cerastoderma sp., $9.79 \%$ and Cardium sp.7.36\% were the next abundant groups. Bivalvia, with 4 genus, had the highest diversity between other groups (Table 2, $3)$.

Average density and biomass percentage of each sample in each season were shown in Table 3. This table showed that, the most average density of macrofauna species was observed in autumn (Pyrgohydrobia sp.) and the least one was related to Nematode $s p$. in spring. Gammarus $s p$. just have seen in winter. The result shows, that maximum abundance between stations belong to station $3\left(2469 \mathrm{n} .0 .05 \mathrm{~m}^{2}\right)$. Also, the minimum frequency of all species was observed in station $4\left(1653 \mathrm{n} .0 .05 \mathrm{~m}^{2}\right)$.

One-way ANOVA showed significant differences in mean abundance, diversity, richness and evenness among stations. All frequency data were natural $\log (\mathrm{X}+1)$ transformed and normalized. The highest mean abundance of species $(804.33 \pm 24.88)$ was obtained at station 3 and the lowest $(607.00 \pm 94.33)$ were at stations 1 . The highest diversity index $(1.317 \pm 0.05)$ was obtained at station 4 while the lowest $(1.095 \pm 0.06)$ was observed at station 1 . The maximum and minimum of the evenness index were obtained at stations 4 and 1, respectively, while the maximum of the richness index was recorded in station 1, but stations (Table 5).

The results of distance-based redundancy analysis (db-RDA) revealed that, environmental variables had significant effects on the spatial distribution of macro benthic animals, (Fig.1). The RDA revealed relationships among 10 species and environmental variables (Fig. 1).

The lines of Shannon index showed that 3 station was more variable than others in all seasons except spring. The RDA demonstrated that in all seasons, depth, Turb, NH3 were influential factors in stations while the other ones were less effective. Bivalves and Gastropods showed the most dependency to BOD5 in spring and temperature in summer .Cerastoderma $s p$. and Hypania $s p$. were relationship with smaller depth, SD and EC in spring. Cerastoderma $s p$. and Hypania $s p$. showed the most dependency to salinity, temperature, $\mathrm{pH}$ and TDS in summer. Whereas Dreissana sp. indicated that it can be dependent to SD and EC in autumn. Hypania was found in regions with more $\mathrm{NH}_{3}$ and Cyanobacteria in summer and winter. 
Table 1. Mean environmental factors measured during this study

\begin{tabular}{|c|c|c|c|c|c|c|}
\hline Season & Station & Temp. $\left(\mathrm{C}^{\circ}\right)$ & $\mathrm{D}(\mathrm{Cm})$ & $\mathrm{DO}(\mathrm{mg} / \mathrm{l})$ & $\mathrm{pH}$ & TDS (mg/l) \\
\hline \multirow{5}{*}{ Spring } & 1 & $22.78 \pm 3.31$ & $70.78 \pm 10.08^{c}$ & $8.48 \pm 0.23$ & $9.04 \pm 0.06^{b}$ & $9.90 \pm 0.55$ \\
\hline & 2 & $22.60 \pm 3.68$ & $103.33 \pm 15.21^{\mathrm{bc}}$ & $9.23 \pm 0.53$ & $9.10 \pm 0.03^{\mathrm{a}}$ & $9.67 \pm 0.27$ \\
\hline & 3 & $22.38 \pm 3.57$ & $113.33 \pm 26.92^{a b}$ & $9.09 \pm 0.58$ & $9.11 \pm 0.04^{\mathrm{a}}$ & $9.91 \pm 0.30$ \\
\hline & 4 & $22.46 \pm 4.49$ & $146.11 \pm 51.77^{\mathrm{a}}$ & $9.07 \pm 0.68$ & $9.12 \pm 0.04^{\mathrm{a}}$ & $9.87 \pm 0.32$ \\
\hline & 5 & $22.94 \pm 3.71$ & $119.89 \pm 49.85^{a b}$ & $9.05 \pm 0.53$ & $9.11 \pm 0.04^{\mathrm{a}}$ & $9.79 \pm 0.29$ \\
\hline \multirow{5}{*}{ Summer } & 1 & $29.20 \pm 0.87$ & $100.00 \pm 15.61^{b}$ & $8.46 \pm 0.13$ & $8.73 \pm 0.24$ & $13.19 \pm 0.16^{\mathrm{a}}$ \\
\hline & 2 & $29.90 \pm 2.26$ & $102.89 \pm 12.81^{b}$ & $8.12 \pm 0.33$ & $8.68 \pm 0.08$ & $13.07 \pm 0.27^{\mathrm{a}}$ \\
\hline & 3 & $30.30 \pm 1.16$ & $134.67 \pm 38.82^{a b}$ & $8.10 \pm 0.24$ & $8.70 \pm 0.26$ & $12.77 \pm 0.35^{b}$ \\
\hline & 4 & $29.99 \pm 1.11$ & $147.11 \pm 40.81^{\mathrm{a}}$ & $7.99 \pm 0.25$ & $8.87 \pm 0.08$ & $12.78 \pm 0.30^{b}$ \\
\hline & 5 & $30.61 \pm 0.68$ & $124.33 \pm 50.42^{a b}$ & $8.27 \pm 0.21$ & $8.76 \pm 0.23$ & $12.64 \pm 0.42^{b}$ \\
\hline \multirow{5}{*}{ Autumn } & 1 & $20.02 \pm 6.56$ & $69.44 \pm 19.76$ & $9.82 \pm 1.36$ & $8.87 \pm 0.33$ & $12.49 \pm 0.55$ \\
\hline & 2 & $19.68 \pm 6.94$ & $83.78 \pm 7.61$ & $9.94 \pm 0.91$ & $9.68 \pm 0.04$ & $12.69 \pm 0.30$ \\
\hline & 3 & $20.11 \pm 7.24$ & $92.78 \pm 14.39$ & $10.05 \pm 0.36$ & $9.09 \pm 0.13$ & $12.58 \pm 0.23$ \\
\hline & 4 & $20.50 \pm 7.38$ & $119.44 \pm 33.77$ & $10.10 \pm 0.16$ & $9.09 \pm 0.15$ & $12.56 \pm 0.17$ \\
\hline & 5 & $20.21 \pm 7.67$ & $103.89 \pm 41.89$ & $10.13 \pm 0.42$ & $9.06 \pm 0.18$ & $12.51 \pm 0.24$ \\
\hline \multirow{5}{*}{ Winter } & 1 & $12.00 \pm 1.65$ & $61.11 \pm 16.16^{\mathrm{c}}$ & $10.91 \pm 0.81$ & $8.89 \pm 0.10$ & $10.10 \pm 0.92$ \\
\hline & 2 & $11.51 \pm 1.95$ & $86.33 \pm 13.54^{b c}$ & $10.70 \pm 0.60$ & $9.30 \pm 0.43$ & $11.03 \pm 0.90$ \\
\hline & 3 & $11.59 \pm 1.94$ & $95.55 \pm 16.29^{b}$ & $10.68 \pm 0.47$ & $9.07 \pm 0.04$ & $11.13 \pm 0.88$ \\
\hline & 4 & $11.72 \pm 1.86$ & $131.31 \pm 42.48^{\mathrm{a}}$ & $10.66 \pm 0.61$ & $9.10 \pm 0.04$ & $11.12 \pm 0.87$ \\
\hline & 5 & $11.64 \pm 1.79$ & $109.00 \pm 44.06^{\mathrm{ab}}$ & $10.61 \pm 0.57$ & $9.05 \pm 0.06$ & $11.10 \pm 0.89$ \\
\hline
\end{tabular}

- Different letters show significant difference between columns $(p<0.05)$.

Table 1. Mean environmental factors measured during this study

\begin{tabular}{ccccccc}
\hline Season & Station & $\mathrm{BOD}_{5 .}(\mathrm{mg} / \mathrm{l})$ & $\mathrm{COD}(\mathrm{mg} / \mathrm{l})$ & $\mathrm{NO}_{2}{ }^{-}(\mathrm{mg} / \mathrm{l})$ & $\mathrm{NH}_{3}{ }^{+}(\mathrm{mg} / \mathrm{l})$ & $\mathrm{PO}_{4}{ }^{3-}(\mathrm{mg} / \mathrm{l})$ \\
\hline \multirow{5}{*}{ Spring } & 1 & $4.21 \pm 0.60^{\mathrm{b}}$ & $86.00 \pm 6.24^{\mathrm{ab}}$ & $0.008 \pm 0.00^{\mathrm{bc}}$ & $0.40 \pm 0.01^{\mathrm{c}}$ & $0.007 \pm 0.00$ \\
& 2 & $5.24 \pm 0.73^{\mathrm{a}}$ & $90.50 \pm 2.73^{\mathrm{a}}$ & $0.020 \pm 0.00^{\mathrm{a}}$ & $0.81 \pm 0.13^{\mathrm{a}}$ & $0.037 \pm 0.01$ \\
& 3 & $3.24 \pm 0.57^{\mathrm{c}}$ & $76.50 \pm 0.56^{\mathrm{d}}$ & $0.009 \pm 0.00^{\mathrm{b}}$ & $0.72 \pm 0.07^{\mathrm{ab}}$ & $0.020 \pm 0.00$ \\
& 4 & $3.78 \pm 0.34^{\mathrm{bc}}$ & $78.50 \pm 6.02^{\mathrm{cd}}$ & $0.012 \pm 0.00^{\mathrm{b}}$ & $0.60 \pm 0.04^{\mathrm{abc}}$ & $0.037 \pm 0.01$ \\
& 5 & $3.81 \pm 0.54^{\mathrm{bc}}$ & $82.00 \pm 2.29^{\mathrm{bc}}$ & $0.004 \pm 0.00^{\mathrm{c}}$ & $0.50 \pm 0.06^{\mathrm{bc}}$ & $0.033 \pm 0.01$ \\
\hline \multirow{3}{*}{ Summer } & 1 & $2.60 \pm 0.92$ & $85.56 \pm 25.29^{\mathrm{ab}}$ & $0.017 \pm 0.00^{\mathrm{a}}$ & $1.32 \pm 0.53^{\mathrm{a}}$ & $0.360 \pm 0.2$ \\
& 2 & $2.57 \pm 0.59$ & $88.57 \pm 27.16^{\mathrm{a}}$ & $0.014 \pm 0.00^{\mathrm{a}}$ & $0.16 \pm 0.03^{\mathrm{b}}$ & $0.173 \pm 0.07$ \\
& 3 & $2.53 \pm 0.26$ & $64.71 \pm 3.16^{\mathrm{b}}$ & $0.016 \pm 0.00^{\mathrm{a}}$ & $0.19 \pm 0.07^{\mathrm{b}}$ & $0.023 \pm 0.00$ \\
& 4 & $3.07 \pm 0.22$ & $75.67 \pm 1.51^{\mathrm{ab}}$ & $0.012 \pm 0.00^{\mathrm{ab}}$ & $0.08 \pm 0.02^{\mathrm{b}}$ & $0.360 \pm 0.24$ \\
& 5 & $3.00 \pm 1.01$ & $86.11 \pm 15.38^{\mathrm{ab}}$ & $0.007 \pm 0.00^{\mathrm{b}}$ & $0.11 \pm 0.06^{\mathrm{b}}$ & $0.223 \pm 0.10$ \\
\hline \multirow{5}{*}{ Autumn } & 1 & $2.73 \pm 0.02$ & $76.33 \pm 4.16^{\mathrm{ab}}$ & $0.022 \pm 0.00^{\mathrm{b}}$ & $2.30 \pm 0.06^{\mathrm{ab}}$ & $0.023 \pm 0.00^{\mathrm{a}}$ \\
& 2 & $2.83 \pm 0.54$ & $83.00 \pm 4.58^{\mathrm{a}}$ & $0.027 \pm 0.00^{\mathrm{a}}$ & $2.19 \pm 0.11^{\mathrm{b}}$ & $0.022 \pm 0.00^{\mathrm{a}}$ \\
& 3 & $2.50 \pm 0.43$ & $64.33 \pm 3.05^{\mathrm{c}}$ & $0.017 \pm 0.00^{\mathrm{c}}$ & $1.67 \pm 0.12^{\mathrm{c}}$ & $0.027 \pm 0.00^{\mathrm{a}}$ \\
& 4 & $3.17 \pm 0.31$ & $74.00 \pm 4.58^{\mathrm{b}}$ & $0.018 \pm 0.00^{\mathrm{c}}$ & $1.53 \pm 0.09^{\mathrm{c}}$ & $0.027 \pm 0.00^{\mathrm{a}}$ \\
& 5 & $3.20 \pm 0.56$ & $75.33 \pm 2.31^{\mathrm{b}}$ & $0.017 \pm 0.00^{\mathrm{c}}$ & $2.56 \pm 0.13^{\mathrm{a}}$ & $0.010 \pm 0.00^{\mathrm{b}}$ \\
& & & & & & \\
\hline
\end{tabular}




\begin{tabular}{lllllll}
\hline & 1 & $2.44 \pm 0.20^{\mathrm{b}}$ & $74.25 \pm 4.10^{\mathrm{ab}}$ & $0.028 \pm 0.00^{\mathrm{b}}$ & $1.74 \pm 0.70$ & $0.007 \pm 0.00$ \\
\multirow{3}{*}{ Winter } & 2 & $3.16 \pm 0.42^{\mathrm{a}}$ & $81.50 \pm 4.72^{\mathrm{a}}$ & $0.044 \pm 0.01^{\mathrm{a}}$ & $1.85 \pm 0.54$ & $0.010 \pm 0.00$ \\
& 3 & $1.97 \pm 0.39^{\mathrm{c}}$ & $64.50 \pm 1.73^{\mathrm{c}}$ & $0.036 \pm 0.01^{\mathrm{ab}}$ & $1.32 \pm 0.50$ & $0.025 \pm 0.01$ \\
& 4 & $2.04 \pm 0.32^{\mathrm{bc}}$ & $68.50 \pm 6.95^{\mathrm{bc}}$ & $0.028 \pm 0.01^{\mathrm{b}}$ & $1.52 \pm 0.52$ & $0.022 \pm 0.01$ \\
& 5 & $2.39 \pm 0.49^{\mathrm{bc}}$ & $76.83 \pm 7.11^{\mathrm{ab}}$ & $0.028 \pm 0.01^{\mathrm{b}}$ & $1.42 \pm 0.54$ & $0.015 \pm 0.01$ \\
\hline
\end{tabular}

- Different letters show significant difference between columns $(p<0.05)$.

Table 2. List of macro benthic invertebrate identified in Gorgan Bay

\begin{tabular}{|c|c|c|c|c|}
\hline Phylum & Class & Family & Genus & Abundance \% \\
\hline \multirow[b]{4}{*}{ Mollusca } & \multirow[t]{4}{*}{ Bivalvia } & \multirow{2}{*}{ Cardiidae } & Cerastoderma sp. & 9.79 \\
\hline & & & Cardium sp. & 7.36 \\
\hline & & Semelidae & Abra sp. & 4.43 \\
\hline & & Dreisseniidae (Zebar mussels) & Dreissana sp. & 0.23 \\
\hline & \multirow{2}{*}{$\begin{array}{l}\text { Gastropods } \\
\text { (snails) }\end{array}$} & Hydrobiidae (Pyrgulidae) & Pyrgohydrobia sp. & 33.83 \\
\hline & & Cochliopidae & Heleobia sp. & 26.25 \\
\hline \multirow{3}{*}{ Arthropods } & \multirow{3}{*}{ Crustacean } & Balanidae & Balanus sp. & 11.90 \\
\hline & & Gammaridae & Gammarus sp. & 0.05 \\
\hline & & Crab & - & $0 / 19$ \\
\hline \multirow{2}{*}{ Annelids } & \multirow{2}{*}{ Polychaeta } & Nereidae & Nereis $S p$ & 4.87 \\
\hline & & Terebellida (Ampharetidae) & Hypania sp. & 1.01 \\
\hline Nemathelminthes & Nematodes & - & Nematode sp. & 0.1 \\
\hline
\end{tabular}

Table 3. Average density and biomass percentage of each sample in each season in $\mathrm{m}^{2}$

\begin{tabular}{|c|c|c|c|c|c|c|c|c|c|c|c|c|}
\hline Genus & Spring & & & Summer & & & Autumn & & & Winter & & \\
\hline & density & biomass & $\%$ & Density & biomass & $\%$ & density & biomass & $\%$ & density & biomass & $\%$ \\
\hline Cerastoderma sp. & 2570 & 233.87 & 31.15 & 2670 & 157.53 & 30.36 & 1640 & 109.88 & 19.73 & 2990 & 615.94 & 49.90 \\
\hline Cardium $s p$. & 1880 & 169.2 & 22.54 & 2660 & 159.6 & 30.76 & 880 & 62.48 & 11.22 & 2010 & 203.01 & 16.44 \\
\hline Abra sp. & 2670 & 224.28 & 29.88 & 550 & 24.2 & 4.66 & 550 & 39.95 & 8.79 & 700 & 91 & 7.37 \\
\hline Dreissana sp. & 20 & 4.8 & 0.64 & 60 & 13.8 & 2.66 & 90 & 21.6 & 3.88 & 60 & 15 & 1.22 \\
\hline Pyrgohydrobia sp. & 6160 & 36.96 & 4.49 & 7970 & 47.82 & 9.22 & 12480 & 4.88 & 13.45 & 7490 & 44.94 & 3.64 \\
\hline Heleobia $s p$. & 4070 & 24.42 & 3.25 & 5870 & 35.22 & 6.79 & 11780 & 70.68 & 12.69 & 4740 & 43.44 & 2.30 \\
\hline Balanus sp. & 2030 & 30.45 & 4.06 & 3320 & 49.8 & 9.60 & 3200 & 105.6 & 18.96 & 3440 & 72.24 & 5.85 \\
\hline Gammarus sp. & - & - & - & - & - & - & - & - & - & 50 & 0.45 & 0.04 \\
\hline Crabsp. & 20 & 4.6 & 0.61 & 20 & 19.4 & 3.74 & 40 & 22 & 3.95 & 110 & 113.3 & 9.18 \\
\hline Nereis Sp. & 830 & 21.58 & 2.87 & 1190 & 10.71 & 2.06 & 1590 & 39.75 & 7.14 & 1300 & 49.4 & 4 \\
\hline Hypania & 180 & 0.54 & 0.07 & 260 & 0.78 & 0.15 & 350 & 1.05 & 0.19 & 230 & 0.69 & 0.06 \\
\hline Nematode sp. & 10 & 0.01 & 0.001 & - & - & - & 30 & 0.03 & 0.005 & 60 & 0.06 & 0.004 \\
\hline Total & 20440 & 70.71 & 100 & 24570 & 518.86 & 100 & 32610 & 556.88 & 100 & 23180 & 1234.47 & 100 \\
\hline
\end{tabular}


Table 4. Mean of species number $(S)$, diversity $\left(H^{\prime}\right)$, richness $(D)$, dominate (1-1) and evenness $(J)$ within stations

\begin{tabular}{cccccc}
\hline Station & Species Number $(\mathrm{S})$ & $\begin{array}{c}\text { Pielou's } \\
(\mathrm{J})\end{array}$ & $\begin{array}{c}\text { Shannon-Wiener's } \\
\left(\mathrm{H}^{\prime}\right)\end{array}$ & Simpson (1-D) & $\begin{array}{c}\text { Margalef's } \\
(\mathrm{D})\end{array}$ \\
\hline 1 & $607.00 \pm 94.34^{\mathrm{a}}$ & $0.79 \pm 0.05^{\mathrm{b}}$ & $1.10 \pm 0.06^{\mathrm{b}}$ & $0.40 \pm 0.03^{\mathrm{a}}$ & $0.40 \pm 0.03^{\mathrm{a}}$ \\
2 & $651.00 \pm 25.55^{\mathrm{a}}$ & $0.91 \pm 0.02^{\mathrm{a}}$ & $1.25 \pm 0.02^{\mathrm{a}}$ & $0.31 \pm 0.01^{\mathrm{b}}$ & $0.31 \pm 0.01^{\mathrm{b}}$ \\
3 & $804.33 \pm 24.88^{\mathrm{a}}$ & $0.92 \pm 0.03^{\mathrm{a}}$ & $1.28 \pm 0.04^{\mathrm{a}}$ & $0.31 \pm 0.02^{\mathrm{b}}$ & $0.31 \pm 0.02^{\mathrm{b}}$ \\
4 & $505.67 \pm 123.43^{\mathrm{a}}$ & $0.95 \pm 0.04^{\mathrm{a}}$ & $1.33 \pm 0.05^{\mathrm{a}}$ & $0.28 \pm 0.02^{\mathrm{b}}$ & $0.28 \pm 0.02^{\mathrm{b}}$ \\
5 & $728.67 \pm 135.51^{\mathrm{a}}$ & $0.95 \pm 0.01^{\mathrm{a}}$ & $1.31 \pm 0.02^{\mathrm{a}}$ & $0.29 \pm 0.01^{\mathrm{b}}$ & $0.29 \pm 0.01^{\mathrm{b}}$ \\
\hline
\end{tabular}

Table 5. Mean of species number $(S)$, diversity $\left(H^{\prime}\right)$, richness $(D)$, dominate (1-1) and evenness $(J)$ within seasons

\begin{tabular}{|c|c|c|c|c|c|}
\hline Station & Species Number (S) & $\begin{array}{c}\text { Pielou's } \\
\text { (J) }\end{array}$ & $\begin{array}{c}\text { Shannon-Wiener's } \\
\left(\mathrm{H}^{\prime}\right)\end{array}$ & Simpson (1-D) & $\begin{array}{l}\text { Margalef's } \\
\text { (D) }\end{array}$ \\
\hline Spring & $662.33 \pm 30.28^{\mathrm{b}}$ & $0.88 \pm 0.05^{\mathrm{a}}$ & $1.41 \pm 0.08^{\mathrm{a}}$ & $0.28 \pm 0.03^{\mathrm{a}}$ & $0.62 \pm 0.00^{\mathrm{a}}$ \\
\hline Summer & $819.00 \pm 2.27^{\mathrm{ab}}$ & $0.93 \pm 0.04^{\mathrm{a}}$ & $1.50 \pm 0.06^{\mathrm{a}}$ & $0.24 \pm 0.02^{\mathrm{a}}$ & $0.61 \pm 0.02^{\mathrm{ab}}$ \\
\hline Autumn & $1087.70 \pm 12.13^{\mathrm{a}}$ & $0.94 \pm 0.01^{\mathrm{a}}$ & $1.51 \pm 0.02^{\mathrm{a}}$ & $0.24 \pm 0.01^{\mathrm{a}}$ & $0.57 \pm 0.00^{\mathrm{b}}$ \\
\hline Winter & $772.67 \pm 70.92^{\mathrm{ab}}$ & $0.94 \pm 0.03^{\mathrm{a}}$ & $1.52 \pm 0.04^{\mathrm{a}}$ & $0.24 \pm 0.02^{\mathrm{a}}$ & $0.60 \pm 0.01^{\mathrm{ab}}$ \\
\hline
\end{tabular}




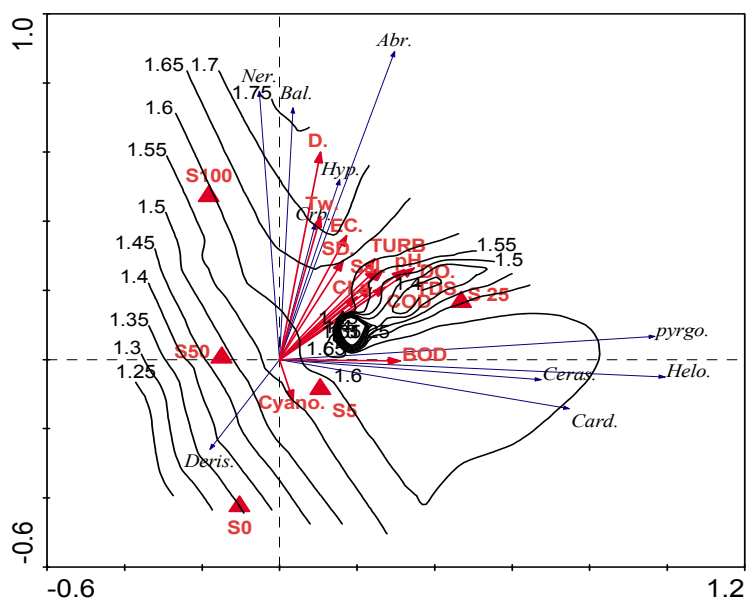

(a)

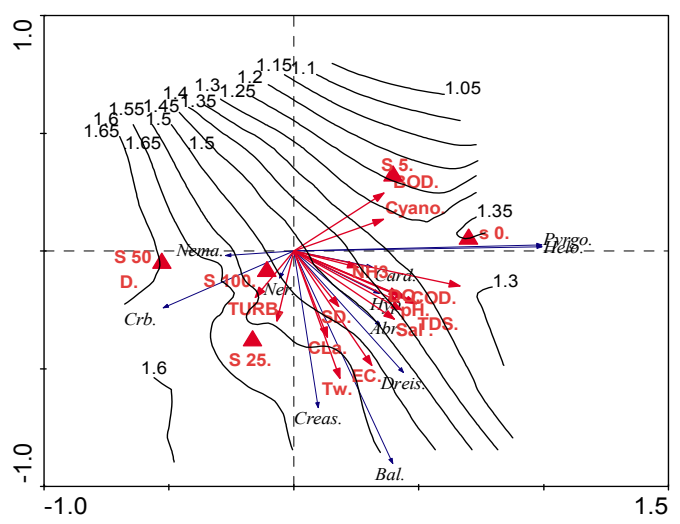

(c)

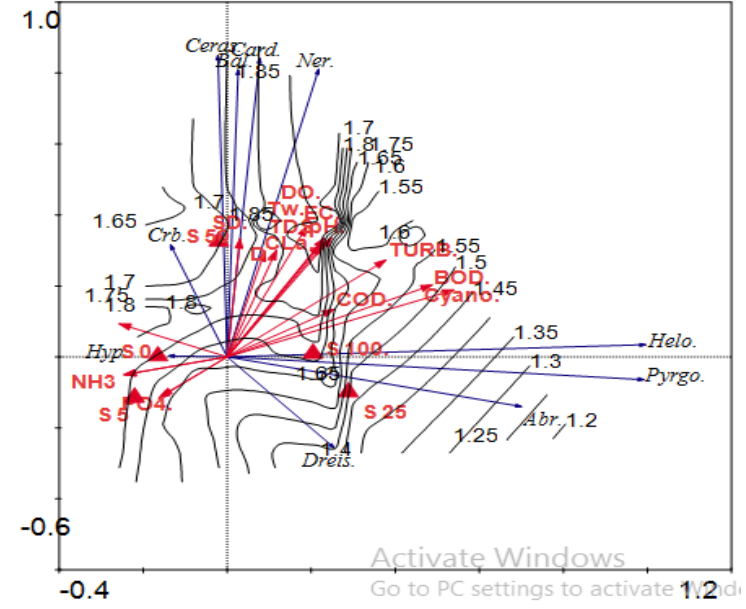

(b)

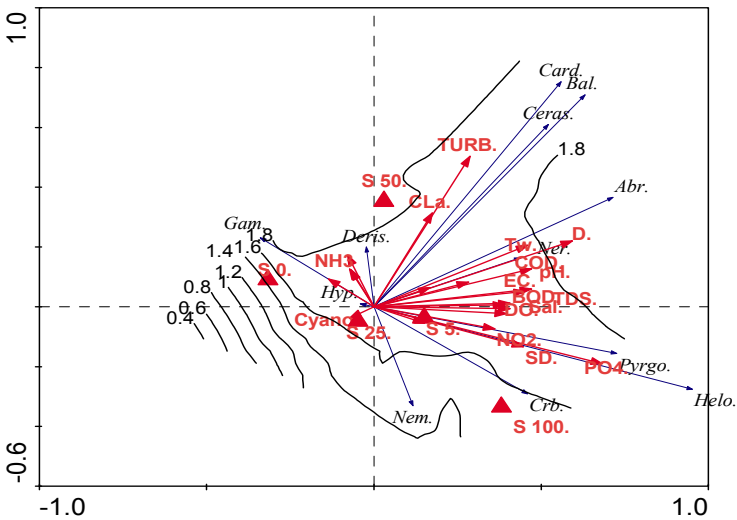

(d)

Figure 2. Results of distance-based redundancy analysis (db-RDA) biplots: (a) Spring (b) Summer (c) Autumn (d) Winter. Arrows indicate environmental variables and different species

\section{Discussion}

Although a lot of species of macrofauna were reported in the Gorgan bay and Caspian Sea (Birshtein et al., 1968; Kasymov, 1994), in comparison, the biodiversity of Caspian is lower than the other seas like the Black Sea and the Barents Sea (Zenkevich, 1963). Low salinity, i.e., (maximum 15 ppt) probably is one of the main reasons, because for true freshwater species it is too high but for marine origin species it is too low. Therefore, these conditions are just favorable for brackish water species (Mordukhai-Boltovskoi, 1979; Karpinsky, 2005). Second reason may be the long geographical isolation of the Caspian Sea from the Black sea (open seas), which began about 5-6 million years ago, which is adequate time for the evolution of unique fauna (Zenkevich, 1963), means that great parts of the Caspian fauna are endemic (Dumont 2000). The south Caspian Sea, with 15 ppt salinity and the highest depth, is a unique ecosystem (Taheri et al., 2012). In Iranian shallow waters, less than 22 species of macrofauna have been reported (Roohi, et al., 2010; Taheri and Yazdani, 2011; Ghasemi, 2011). In the present study, 12 species of macrofauna were identified. In Gorgan Bay, Saghali et al. (2012) found 13 family while Taheri et al. (2012) obtained 8 family macrofauna in the south of Caspian Sea. In Baku Bay, Kasymov (1989) found 9 spices of macrobenthos while Tait et al. (2004) obtained 62 and Parr et al. (2007) identified 71 species of macrofauna at the south of Baku, Azerbaijan. It should be mentioned that the present study such as Saghali et al. (2012) and Taheri et al. (2012) studies were carried out at shallow water, but they sampled from shallow waters to waters nearly $800 \mathrm{~m}$ depth. Although, in the Gorgan Bay some different orders of macrofauna were reported, we did not find communities of small forms such as Cumacea and Mysidacea that had been reported by Kasymov (1994) for the south of Caspian Sea. 
It is necessary to note that different parts of the Gorgan Bay have variable structures in terms of macrofauna communities, because of different environmental conditions (Kasymov, 1994). High species diversity among the macrofauna in marine ecosystems belongs to Polychaeta while fewer than 10 species have been known in the Gorgan Bay up to now (Birshtein et al., 1968; Kasymov, 1989, 1994; Grigorovich et al., 2003; Tait et al., 2004). In this study, only 1 species of Polychaeta's was found. Similar results were observed in the Gorgan Bay and the south-west of the Caspian Sea (Taheri et al., 2007; Bandany et al., 2008), the Gorgan Bay and the south-east of the Caspian (Taheri et al., 2012) and the south of Baku, Azerbaijan (Parr et al., 2007). In our study, Bivalvia, with 4 species, in terms of diversity and density were in second place and they observed in most stations. In other studies, one species (Cerastoderma lamarcki) of Bivalvia was reported in Mazandaran province (Taheri and Yazdani, 2011; Ghasemi, 2011) and two species reported in Gorgan Bay (Taheri et al., 2012). Also, we found some Gastropoda. Similar results were reported by: Ghasemi (2011), who that reported one species of Pyrgula sp. in Mazandaran province and Saghali et al., (2012) reported 3 species in Gorgan Bay, while 16 species were observed in Azerbaijan (Parr et al., 2007).

In this study, Pyrgohydrobia sp. with $33.83 \%$ of the total abundance was the numerically dominant species that they were observed at all of the stations, and Nematode sp. with $0.1 \%$ of the total was the lowest species. Maximum diversity (1.33) and richness (0.40) were very low. Similar results were obtained in the south of Caspian Sea (Taheri et al., 2007; Bandany et al., 2008; Taheri and Yazdani, 2010). The value of these indices could be related to the small number of macrofauna in sampling and existence of the dominant species with very high density in each season.

Results obtained from Canoco software indicated clear spatial differences in macro benthic assemblage structures in relation to environmental variables such as depth, $\mathrm{EC}, \mathrm{NH}^{3}$ and other factors in Gorgan bay. Numerous research have shown that the spatial distribution of macro benthic invertebrates along shallow waters is related to environmental variables (Saghali et al. 2012; Taheri and Yazdani, 2010; Ghasemi et al., 2014; Gogina and Zetller, 2010). Thus, the results of the present study are consistent with those of past studies. While Taheri et al. (2012) reported that they were not found any significant correlations between the density of macrofauna and all the environmental conditions. They offered macrofauna assemblages were controlled by other factors such as different kinds of pollution like heavy metals and rural and agricultural waste water. In this study, Cerastoderma $s p$, showed the most relevance with EC and SD factors in comparison to others in spring and summer.

Seasonal density variation of the macrofauna may be depended to many factors such as breeding activity of macrofauna and predator pressure (Kevrekidis, 2005; Taheri and Yazdani, 2011). The highest density of macrofauna was observed in autumn (32610). This may be related to density of Pyrgohydrobia sp. and Heleobia $s p$. that was maximal in this season. The lowest density of macrofauna was recorded in spring (29449); it may be related to the higher predation rate as reproduction season for many benthivore fish in the Gorgan Bay and Caspian Sea starts from late winter to late spring. Higher metabolic rate, because of increasing in temperature, associated with higher feeding intensity of predators can be the other reason of lowest density in summer.

In conclusion, the present results demonstrated very low biodiversity in terms of macrofauna in Gorgan bay and indicated significant correlations between the density of macrofauna and all various environment conditions.

\section{Acknowledgments}

The author is so thankful to Mr. Roshan, Ballashi and Mira for the assistance in the field samplings. This research was supported by the Department of the Environment

Golestan Head Office.

\section{References}

Abowei, J. F. N., Ezekie, E. N., \& Hansen, U. (2012). Effects of water pollution on benthic macro fauna species composition in Koluama Area, Niger Delta Area, Nigeri. International Journal of Fisheries and Aquatic Sciences, 1(2), 140-146.

Aghili, K., Aghaei Moghadam, A., Tabari, A., \& Hashemi Rostami, A. (2014). The study of macroinverteberates of Gorgan Gulf in common carp pen culture. The first conferences of modern aquaculture. Gorgan University of agriculture sciences and natural resources. 17 p. Gorgan, Iran.

Baldanzi, S., McQuaid, C. D., \& Cannicci, S. (2013). Environmental do- mains and range-limiting mechanisms: testing the abundant Centre hypothesis using southern African sand hoppers. PLOS ONE Journal, 8(1), 1-11. https://doi.org/10.1371/journal.pone.0054598 
Bandany, Gh. A., Akrami, R., Taheri, M., Molla-Gholamali, M., \& Yelghi, S. (2008). Distribution, abundance and biomass of Polychaeta in the north coast of Gorgan Bay. Iranian Scientific Fisheries Journal, 16, 4552.

Birshtein, Y. A., Vinogradov, L. G., Kondakov, N. N., Astakhova, M. S., \& Romanova, N. N. (1968). Atlas of Invertebrates of the Caspian Sea. Pishchevaya Promyshlennost, Moscow. 238p.

Braak, C. J. F., \& Smilauer, P. (2002). CANOCO reference manual and Cano Draw for Windows user's guide: software for canonical community ordination (version 4.5).

Conde, A., Novise, J. M., \& Dominguse, J. (2013). Distribution of intertidal macro benthic assemblages in relation to environmental factors in the Tagus estuary, western Portugal. Scientia Marina, 77(1), 179-188. https://doi.org/10.3989/scimar.03628.21E

Dauer, D. M. (1993). Biological criteria, environmental health and estuarine macrobenthic community structure. Marine Pollution Bulletin, 26(5), 249-257. https://doi.org/10.1016/0025-326X(93)90063-P

Dorostkar, A. (2007). The study and identify of macro invertebrate of Gorgan Gulf. Thesis of M.Sc of biology of sea, Tehran University. Abstract.

Dumont, H. J. (2000). Endemism in the Ponto-Caspian fauna, with special emphasis on the Onychopoda (Crustacean). Adv Ecol Res, 31, 181-196. https://doi.org/10.1016/S0065-2504(00)31012-1

Ghasemi, A. F. (2014). Species composition of benthic macroinvertebrates on the coast line vegetated rocky substrates of the southern Caspian Sea. Transylv. Rev. Syst. Ecol. Res., 16, 57-61. https://doi.org/10.1515/trser-2015-0002

Gogina, M., Glockzin, M., \& Zettler, M. L. (2010). Distribution of benthic macrofauna communities in the western Baltic Sea with regard to near-bottom environmental parameters modeling and prediction. Journal of Marian System, 80, 57-70. https://doi.org/10.1016/j.jmarsys.2009.10.001

Grigorovich, I. A., Therriault, T. W., \& MacIsaac, H. J. (2003). History of aquatic invertebrate invasions in the Caspian Sea. Biol. Invasions, 5, 103-115. https://doi.org/10.1023/A:1024050824073

Karpinsky, M. G. (2005). The Caspian Sea Environment. In A. Kostianoy, \& A. Kosarev (Eds.), Biodiversity: The Handbook of Environmental Chemistry (pp. 159-173). Springer-Verleg. https://doi.org/10.1007/698_5_008

Kasymov, A. G. (1989). Abundance of zooplankton and zoo benthos in Baku Bay, Caspian ea. Oceanology, 28(4), 524-526.

Kasymov, A. G. (1994). Ecology of the Caspian Lake. Azerbaijan Publishing, Baku, 238p.

Lahijani, H., Haeri, A. O., \& Sharifi, A. (2002). Sediment logy and mineralogy of Gorgan bay sediments. In: Research Report of the Iranian National Center for Oceanography. Tehran: INIO, 61.

Lahijani, H., Haeri, A. O., \& Sharifi, A. (2010). Sediment logical and Geochemical Characteristics of the Gorgan Bay Sediments. Oceanography, 1(1), 11.

Mordukhai-Boltovskoi, F. D. (1979). Composition and distribution of Caspian fauna in the light of modern data. Int Rev Gesamten Hydrobiol Hydrogr, 64, 1-38. https://doi.org/10.1002/iroh.19790640102

Nicastro, A., \& Bishop, M. J. (2013). Weak and habitat-dependent effects of nutrient pollution on macro fauna communities of southeast Australian Estuaries. PLOS ONE Journal, 8(6), 1-10. https://doi.org/10.1371/journal.pone.0065706

Nyanti, L., Hii, K. M., Sow, A., Norhadi, I., \& Ling, T. Y. (2012). Impacts of aquaculture at different depths and distances from cage culture sites in Batang Ai Hydroelectric Dam Reservoir, Sarawak, Malaysia. World Applied Sciences Journal, 19(4), 451-456.

Parr, T. D., Tait, R. D., Maxon, C. L., Newton, F. C., \& Hardin, J. L. (2007). A descriptive account of benthic macrofauna and sediment from an area of planned petroleum exploration in the southern Caspian Sea. Estuar Coast Shelf Sci, 71, 170-180. https://doi.org/10.1016/j.ecss.2006.07.018

Roohi, A., Kideys, A. E., Sajjadi, A., Hashemian, A., Pourgholam, R., Fazli, H., ... Eker-Develi, E. (2010). Changes in biodiversity of phytoplankton, zooplankton, fishes and macrobenthos in the Southern Caspian Sea after the invasion of the ctenophore. Mnemiopsis Leidyi. Biol Invasions, 12, 2343-2361. https://doi.org/10.1007/s10530-009-9648-4 
Saghali, M., Bagheroof, R., Patimar, R., Hoseini, S. A., \& Makhtoomi, N. M. (2012). Abundance and biomass macroinvertebrate of Gorgan Gulf, Golestan. 45-56.

Sanz-Lázaro, C., \& Marín, A. (2011). Diversity patterns of benthic macrofauna caused by marine fish farming. Diversity, 3, 176-199. https://doi.org/10.3390/d3020176

Sharbaty, S. (2012). 3-D simulation flow pattern in the Gorgan Bay in during summer. International Journal of Engineering Research and Applications, 2(3), 700-707.

Snickars, M., Gullström, M., \& Sundblad, G. (2013). Species-environment relationships and potential for distribution modeling in coastal waters. Journal of Sea Research, 85, 116-125. https://doi.org/10.1016/j.seares.2013.04.008

Taheri, M., \& Yazdani, M. (2011). Community structure and biodiversity of shallow water macrobenthic fauna at Noor coast, South Caspian Sea, Iran. J Mar Biol Ass UK, 91(3), 607-613. https://doi.org/10.1017/S0025315410000378

Taheri, M., Seyfabadi, J., \& Yazdani Foshtomi, M. (2007). Ecological study and species identification of polychaetes of Gorgan Bay (Bandargaz Coast). Iranian Journal of Biology, 20, 286-294.

Taheri, M., Yazdani, M., Noranian, M., \& Mira, S. SH. (2012). Spatial Distribution and Biodiversity of Macrofauna in the Southeast of the Caspian Sea, Gorgan Bay in Relation to Environmental Conditions. Ocean Sci. J, 47(2), 113-122. https://doi.org/10.1007/s12601-012-0012-8

Tait, R. D., Maxon, C. L., Parr, T. D., Newton, F. C., \& Hardin, J. L. (2004). Impact assessment and benthic recruitment following exploration drilling in the South Caspian Sea. 7th SPE international conference on health, safety, and environment in oil and gas exploration. Calgary. Canada. Mar., 12, 29-31. https://doi.org/10.2118/86709-MS

Tajari, M., Razieei, M., Afsa, S., Azimi, A., Shamekhi, Kh., \& Hami, A. (2013). The study of abundance and biomass macroinvertebrate in Gomishan Wetland. Animal Biology, 6(2), 11-19.

Zenkevitch, L. A. (1963). Biology of the USSR Seas. AN SSSR, Moscow, 956 p.

\section{Copyrights}

Copyright for this article is retained by the author(s), with first publication rights granted to the journal.

This is an open-access article distributed under the terms and conditions of the Creative Commons Attribution license (http://creativecommons.org/licenses/by/4.0/). 